\title{
МЕТОДИЧНІ АСПЕКТИ СКЛАДАННЯ РОБОЧОГО ПЛАНУ РАХУНКІВ ЗА МСФЗ ДЛЯ КОМПАНІЙ АВТОМОБІЛЬНО-ДОРОЖНЬОГО КОМПЛЕКСУ
}

\author{
Ковальова Т.В. канд. екон. наук, доцент \\ Харківський національний автомобільно-дорожній університет
}

\section{Постановка проблеми та їі зв'язок із практичними завданнями.} Автомобільно-дорожній комплекс $є$ ключовим елементом економіки країни. Його ефективне функціонування напряму пов'язано з бухгалтерським обліком, оскільки останній є складовою системи управління. Сьогодні міжнародна інтеграція у сфері економіки призвела до необхідності застосування в нашій країні зрозумілих для інвесторів принципів формування інформації про господарську діяльність підприємств та ії оприлюднення. Звітність підприємства, складена за міжнародними стандартами дає змогу проводити фінансовий аналіз суб'єкта господарювання, за результатами якого буде здійснюватись прогноз щодо майбутньої діяльності цього суб'єкта, розробляти шляхи зменшення ризиків і т. ін. Міжнародні стандарти фінансової звітності стали інструментом світових господарських зв'язків, дали можливість залучити закордонних інвесторів та розширити експортні можливості України, які в свою чергу приведуть до зниження безробіття, забезпечать вихід з кризи та майбутнє процвітання економіки [1]. При складання звітності за міжнародними стандартами важливим $\epsilon$ система бухгалтерських рахунків, які згруповані певним чином, і повинні забезпечити облік і контроль господарської діяльності як у межах окремих підприємств та країн, так і на міжнародному рівні [2]. У разі використання міжнародних стандартів, бухгалтерська служба зобов'язана розробити такий план рахунків, який би забезпечував достовірну, швидку обробку інформації та правильний іiі аналіз. Оскільки, економічна діяльність $\epsilon$ розгалуженою, то і план рахунків повинен відображати ці особливості. Діяльність підприємств автомобільно-дорожнього комплексу не $\epsilon$ виключенням. Тому у статті буде розглянуто підходи до складання робочого плану рахунків, за умови використання підприємствами автомобільнодорожнього комплексу міжнародних стандартів обліку та звітності, враховуючи особливості виду діяльності цих компаній.

Аналіз останніх досліджень та публікацій показав, що питанням щодо складання плану рахунків за міжнародним стандартами займались значна кількість науковців, при чому вони розглядали різні аспекти цього процесу. Так, Л. Г. Ловінська, О. О. Канцуров, В. Г. Швець, Б. А. Засадний, Т. Г. Мельник, Г. П. Голубнича, О. І. Малишкін, К. В. Бойко, Т. О. Матвієнко звернули увагу на роль та значення плану рахунків в умовах застосування міжнародних стандартів фінансової звітності [2]. Безверхий К. розглянув 
підготовку Плану рахунків бухгалтерського обліку при першому застосуванні МСФ3, крім того він запропонував його основні розділи [3]. Деякі автори проводили аналіз структури плану рахунків різних країн [4]. Розробку робочого плану рахунків бухгалтерського обліку 3 метою гармонізації інформаційного забезпечення економічної безпеки суб'єктів міжнародного економічного середовища у своїй роботі розглядали Гнилицька Л. В. та Безверхий К. В. [5]. Цвєктова Н.М. розглянула методологічні питання побудови системи рахунків на підприємствах за МСФЗ [6].

Невирішені складові загальної проблеми. Не зменшуючи наукових досягнень провідних науковців, зауважимо, що досліджень щодо складання робочого плану рахунків, враховуючи вимоги міжнародних стандартів, і його залежність від виду економічної діяльності майже не має. Більшість робіт науковців передбачають вивчення проблеми складання робочого плану рахунків за національними стандартами, без врахування вимог МСФО та МСФЗ.

Формулювання цілей статті. Ціль статті - дослідження методичних та концептуальних підходів щодо побудови робочого плану рахунків для компаній автомобільно-дорожнього комплексу враховуючи вимоги міжнародних стандартів.

Виклад основного матеріалу дослідження. Відразу зазначимо, що МСФЗ не містять плану рахунків і не регулюють питання його застосування. Саме тому бухгалтерській службі підприємств слід самостійно розробляти та впроваджувати власний (робочий) план рахунків, спираючись при цьому на затверджені МСФЗ. При розробці робочого плану рахунків, незалежно від галузі економічної діяльності, бухгалтерській службі слід керуватись МСБО 1 «Подання фінансової звітності», у якому вказані основні елементи, зміст яких знаходить своє відображення в звітності за МСФЗ. Слід також керуватись i МСФ3 1 «Перше застосування Міжнародних стандартів фінансової звітності». Українське законодавство не регламентує порядок відображення інформації у системі рахунків компаніями, які складають звітність за МСФЗ. На відміну від національних стандартів міжнародні стандарти фінансової звітності не регламентують, яким повинен бути план рахунків. Отже, компанії автомобільно-дорожнього комплексу, які здійснюють ведення обліку i складання фінансової звітності відповідно до МСФЗ, можуть розробити i використовувати власний (робочий) план рахунків, відмінний від плану рахунків інших підприємств. Іншими словами, робочий план рахунків за МСФ3 розробляється компаніями самостійно, без будь-якої вказівки зверху, враховуючи особливості своєї господарської діяльності та форм звітності.

Бухгалтерські служби компаній автомобільно-дорожнього комплексу, які складають звітність за МСФЗ, при розробці робочого плану рахунків повинні брати до уваги наступне. По - перше - структуру фінансової звітності та забезпечення зручного складання основної фінансової звітності. Рахунки слід називати відповідно до статей і показників звітності, це буде сприяти більш вірному відображенню суті бухгалтерських операцій i більш точному 
формуванню основних i додаткових форм фінансової та управлінської звітності. По - друге, план рахунків повинен забезпечити можливість розширення в майбутньому через зміни в структурі або напрямку бізнесдіяльності компанії; і по-третє - достатня деталізація рахунків для створення управлінських і фінансових звітів. Іще одна 3 найважливіших характеристик будь-якого плану рахунків - це ув'язка 3 автоматизованою обліковою системою. Він повинен бути гнучким по відношенню до автоматизованої системи, яка або діє на підприємстві, або може використовуватись у майбутньому. Також, ураховуючи стрімкий розвиток галузей економічної діяльності, ми пропонуємо передбачити декілька вільних рахунків у кожному класі. Це забезпечить гнучкість плану і задовольнить потреби, які будуть виникати у майбутньому.

Білоус О.С. вказує на складність процесу створення робочого плану рахунків і наголошує на проведення наступних заходів: 1) Підготовчий - аналіз чинного законодавства 3 бухгалтерського обліку. Ознайомлення з умовами діяльності, організаційною структурою, економічною політикою установи. Ознайомлення 3 особливостями організації бухгалтерського обліку. 2) Організаційний - підбір осіб, відповідальних за розробку робочого плану рахунків, і визначення їх правового статусу. Визначення термінів та алгоритму розробки робочого плану рахунків. 3) Технологічний - вибір ознак виділення рахунків. Визначення кількості рівнів узагальнення інформації та критеріїв віднесення рахунків до різних рівнів. Виділення синтетичних і аналітичних рахунків, їх ранжування. Вибір системи кодування та його здійснення. 4) Завершальний - визначення формату представлення робочого плану рахунків (документальне оформлення). Опис змісту робочого плану рахунків. Упровадження, контроль за впровадженням i дотриманням, виявлення недоліків і внесення змін [7].

Розглянемо детально ці заходи, в контексті підприємств автомобільнодорожнього комплексу, що використовують МСФЗ. Ураховуючи вище наведену інформацію, бухгалтерській службі компаній автомобільнодорожнього комплексу, на підготовчому етапі, крім аналізу відповідної нормативно-законодавчої бази, необхідно консультуватися 3 менеджерами i ретельно продумувати, які саме рахунки повинні бути у складі робочого плану рахунків, для того, щоб була можливість проводити аналіз діяльності компанії, що $є$ важливим при використанні МСФЗ. Авторка статті згодна 3 думкою К. Боримською, яка зауважує що будуючи та впроваджуючи в практику робочий план рахунків, важливо чітко визначити показники діяльності підприємства, що відображаються в системі, знайти баланс між максимально можливою глибиною аналітики та витратами на ï облік, адже розроблений підприємством робочий план рахунків повинен бути гнучким i зручним у використанні [8]. Організація обліку в компаніях автомобільно-дорожнього комплексу має певні особливості, які пов'язані зі специфікою виробничого процесу. До особливостей, наприклад, виробничого процесу автотранспортних підприємств, Яковенко С.Л., Минич Ю.В. відносять наступне: автотранспорт не 
пов'язаний із сировиною та іiі переробкою; важливими $є$ технічне обслуговування i ремонт рухомого складу автотранспортних засобів, придбання, зберігання та використання паливно-мастильних матеріалів, автомобільних шин і т. ін.; автомобільні перевезення виконуються різними типами і видами автотранспортних засобів, тому облік витрат і доходів та визначення ефективності діяльності ведеться окремо як за видами транспортних засобів, так i за видами перевезень; робота автомобільного транспорту $є$ соціально дуже важливою і відповідальною, тому виробничий процес ретельно оформлюється відповідними документами і контролюється органами державного контролю. Крім того, перевезення пасажирів автотранспортом детально регламентуються багатьма законодавчими i нормативно-правовими актами, які останнім часом часто змінюються та доповнюються [9]. Дорожне господарство, як складова автомобільнодорожнього комплексу теж має свої особливості. Воно включає автомобільні дороги, інженерні комунікації державних i приватних підприємств i організацій, що їх обслуговують. Ці підсистеми є досить складними, мають свої особливості i як в обліку так i в аналізі. Облік у системі дорожнього господарства, особливо, якщо він ведеться за МСФ3, повинен упорядкувати інформацію, яка необхідна користувачам, забезпечити іiі якість і контроль за діяльністю компаній. Велике значення при розробці робочого плану рахунків має компетентність бухгалтерських кадрів. Вони повинні мати змогу зводити до мінімуму розбіжності в оцінці результатів господарсько-економічної діяльності у процесі використання міжнародних стандартів.

Немає єдиної точки зору науковців щодо визначення кількості рівнів узагальнення інформації та критеріїв віднесення рахунків до різних рівнів та виділення синтетичних і аналітичних рахунків. Аналітики компанії «Фінансова Академія Актив» [4], запропоновували структуру робочого плану рахунків, беручи до уваги вимоги МСФЗ. Так вони наголошують, що основними розділами робочого плану рахунків слід зробити наступні: необоротні активи; оборотні активи; капітал; довгострокові зобов'язання; короткострокові зобов'язання; доходи; витрати; рахунки управлінського обліку; позабалансові рахунки. Порівнюючи ці розділи із затвердженим у нашій країні Планом рахунків бухгалтерського обліку активів, капіталу, зобов'язань і господарських операцій підприємств і організацій, слід звернути увагу на відсутність у ньому окремих розділів «доходи»; «витрати» та «рахунки управлінського обліку». У свою чергу, Безверхий К. уточнює, що існує три основні підходи до побудови Плану рахунків бухгалтерського обліку за МСФЗ. Перший підхід полягає в розширенні вже існуючого Плану рахунків бухгалтерського обліку за НП(С)БО згідно МСФ3. Другий підхід пропонує використовувати загальноприйняті принципи побудови Плану рахунків бухгалтерського обліку у відповідності до англосаксонської моделі обліку. Третім підходом є синтез елементів першого і другого підходів до побудови Плану рахунків бухгалтерського обліку за МСФ3 [3]. Існує точка зору, що будь-який план рахунків, складений за МСФЗ, відображає п’ять основних елементів фінансової звітності: активи, 
зобов'язання, капітал, доходи та витрати [10]. Гнилицька Л. В. та Безверхий К. В. довели доцільність використання підприємствами англосаксонського варіанту побудови плану рахунків. Цей варіант вирізняється з поміж інших тим, що назви рахунків бухгалтерського обліку максимально наближені до аналогічних статей фінансової звітності [5].

Ураховуючи вище наведену інформацію, компанії автомобільнодорожнього комплексу можуть мати наступний план рахунків: 100 клас «Необоротні акти»; 200 - «Оборотні активи»; 300 - «Власний капітал та резерви»; 400 - «Довгострокові зобов'язання»; 500 - «Короткострокові зобов'язання»; 600 - «Дохід»; 700 - «Витрати»; 800 - «Інші доходи та витрати». При розробці робочого Плану рахунків бухгалтерського обліку за МСФЗ для компаній автомобільно-дорожнього комплексу слід особливу увагу звертати на кодифікацію рахунків. Науковці вважають, що кодифікація повинна враховувати не лише формат фінансової звітності, але й вимоги користувачів стосовно класифікації, оцінки та контролю за наявністю (використанням) окремих активів чи зобов'язань. Досвід господарювання великих груп підприємств показує, що для забезпечення аналітичних потреб достатньо використовувати п’яти - восьмизначну нумерацію коду [5]. Далі вони наводять приклад: шифр 101.4.1 вказує, що мова йде про основні засоби (101 - шифр синтетичного рахунку), їх окрему групу (4 - машини та обладнання), що знаходяться в експлуатації (1 - основний засіб в експлуатації) [5]. Як уже зазначалось, велике значення при веденні обліку за міжнародними стандартами відводиться аналітиці, про що і свідчить наведений приклад.

Висновки і перспективи подальших досліджень. Підводячи підсумок щодо вище викладеного слід зазначити наступне. МСФЗ не регламентують створення робочого плану рахунків. При його формуванні компаніям автомобільно-дорожнього комплексу, які використовують МСФЗ, необхідно враховувати особливості діяльності підприємства, стан обліку та компетентність бухгалтерських кадрів. При розробці робочого плану рахунків можна використовувати англосаксонський варіант побудови плану рахунків, оскільки він забезпечує найбільшу його аналітичність та відповідність статтям звітності. Обов'язково в його складі повинні бути рахунки, що не мають назв, які за необхідності будуть заповнені та введені в дію, що забезпечить гнучкість робочого плану та ще більше підкреслить його аналітичність.

У подальшому слід продовжити роботу в частині регламентації та складу синтетичних рахунків та субрахунків за кожним класом робочого плану рахунків з урахуванням МСФЗ.

\section{Перелік посилань}

1. Конопліна О. О., Назаренко А. О. Проблеми впровадження міжнародних стандартів фінансової звітності в Україні. URL: https://core.ac.uk/download/pdf/225542961.pdf (дата звернення: 10.09.2021).

2. Нормативно-методичне забезпечення бухгалтерського обліку в умовах застосування міжнародних стандартів фінансової звітності / за заг. ред. Л. Г. Ловінської. Київ: ДННУ “Акад. фін. управління”, 2013. 294 с. 
3. Безверхий К. План рахунків бухгалтерського обліку для цілей складання фінансової звітності за MCФ3. URL: file:///C:/Users/Professional/Downloads/boau_2014_7_4\%20(2).pdf （дата звернення: 07.08.2021).

4. Петенева Е. Клевец А. План счетов МСФО: отличия от национальных стандартов и пример составления. URL: https://finacademy.net/materials/article/plan-schetov-msfo-otlichiya-otnatsionalnykh-standartov-i-primer-sostavleniya. (дата звернення: 07.08.2021).

5. Гнилицька Л. В., Безверхий К. В. Розробка робочого плану рахунків бухгалтерського обліку 3 метою гармонізації інформаційного забезпечення економічної безпеки суб'єктів міжнародного економічного середовища. URL: https://er.knutd.edu.ua/bitstream/123456789/195/1/\%D0\%A1\%D1\%82\%D0\%B0\%D 5\%D0\%B8\%D0\%B9.pdf. (дата звернення: 10.09.2021).

6. Цвєктова Н.М. Методологічні питання побудови системи рахунків на підприємствах за МСФ3. URL: http://194.44.12.92:8080/jspui/bitstream/123456789/2484/1/2.2.2016.PDF. (дата звернення: 01.09.2021).

7. Білоус О.С. Загальні засади розробки робочого плану рахунків бюджетних установ.

URL: https://dspace.uzhnu.edu.ua/jspui/bitstream/lib/18956/1/\%D0\%91\%D1\%96\%D0\%B B\%D0\%BE\%D1\%83\%D1\%81\%20\%D0\%9E.\%D0\%A1..PDF. (дата звернення: 11.09.2021).

8. Боримська К.П. Порядок побудови робочого плану рахунків як елемента облікової політики підприємства. URL: http://dspace.kntu.kr.ua/jspui/bitstream/123456789/258/1/49.pdf. (дата звернення: 11.09.2021).

9. Яковенко С.Л., Минич Ю.В. Особливості обліку на автотранспортних підприємствах. http://molodyvcheny.in.ua/files/journal/2019/1/58.pdf. (дата звернення: 10.09.2021).

10. Счетоведение: Монография в 3-х частях. Ч. II. Планы счетов бухгалтерского учета / Н.М. Малюга, М.Я. Штейнман, Е.П. Боримская [Предисл. Ф.Ф. Бутынца]. Житомир: ЖГТУ, 2009. 396 с.

\section{References.}

1. Konoplina, O.O, Nazarenko, A.A. (2018). Problems of implementation of international financial reporting standards in Ukraine [Problemy vprovadzhennya mizhnarodnykh standartiv finansovoyi zvitnosti $\mathrm{v}$ Ukrayini], available at: https://core.ac.uk/download/pdf/225542961.pdf (last accessed 10.09.2021).

2. Regulatory and methodological support of accounting in terms of application of international international standards of financial reporting standards / for general. ed. LG Lovinskaya. [Normatyvno-metodychne zabezpechennya bukhhalters'koho bukhhalters'koho obliku $\mathrm{v}$ umovakh zastosuvannya zastosuvannya mizhnarodnykh mizhnarodnykh standartiv standartiv finansovoyi finansovoyi zvitnostii]. Kyiv: DNNU “Acad. Finn. management”, 2013.294 p. 
3. Bezverkhy, K. (2014). Chart of accounts for the purposes of preparing financial statements in accordance with IFRS. [Plan rakhunkiv bukhhalters'koho obliku dlya tsiley skladannya finansovoyi zvitnosti za MSFZ], available at: file: /// C: / Users / Professional / Downloads / boau_2014_7_4\% 20 (2)pdf (last accessed 07.08.2021).

4. Peteneva, E. Klevets, A. (2020). Plan of accounts IFRS: differences from national standards and an example of compilation. [Plan schetov MSFO: otlichiya ot natsional'nykh standartov $i$ primer sostavleniya], available at: https://finacademy.net/materials/article/plan-schetov-msfo-otlichiya-otnatsionalnykh-standartov-i-primer-sostavleniya. (last accessed 07.08.2021).

5. Gnylytska, L.V. \& Bezverkhy, K.V. (2015). Development of a working plan of accounting accounts in order to harmonize the information support of economic security of the international economic environment. [Rozrobka robochoho planu rakhunkiv bukhhalters'koho obliku $\mathrm{z}$ metoyu harmonizatsiyi informatsiynoho zabezpechennya ekonomichnoyi bezpeky sub"yektiv mizhnarodnoho ekonomichnoho seredovyshcha], available at: https://er.knutd.edu.ua/bitstream/123456789/195/1/\%D0\%A1\%D1\%82\%D0\%B0\%D 5\%D0\%B8\%D0\%B9.pdf. (last accessed 10.09.2021).

6. Tsvektova, N.M. (2014). Methodological issues of building a system of accounts at enterprises under IFRS. [Metodolohichni pytannya pobudovy systemy rakhunkiv na pidpryyemstvakh za MSFZ], available at: http://194.44.12.92:8080/jspui/bitstream/123456789/2484/1/2.2.2016.PDF. (last accessed 01.09.2021).

7. Belous, O.S. (2018). General principles of development of the working plan of accounts of budgetary institutions [Zahal'ni zasady rozrobky robochoho planu rakhunkiv byudzhetnykh ustanov], available at: https://dspace.uzhnu.edu.ua/jspui/bitstream/lib/18956/1/\%D0\%91\%D1\%96\%D0\%B B\%D0\%BE\%D1\%83\%D1\%81\%20 \% D0\% 9E.\% D0\% A1.PDF(last accessed 11.09.2021).

8. Borimskaya, K.P. (2010). The order of construction of the working plan of accounts as an element of the accounting policy of the enterprise [Poryadok pobudovy robochoho planu rakhunkiv yak elementa oblikovoyi polityky pidpryyemstva], available

at: http://dspace.kntu.kr.ua/jspui/bitstream/123456789/258/1/49.pdf. (last accessed 11.09.2021).

9. Yakovenko, S.L., Minich, Yu.V. (2019). Features of accounting at motor transport enterprises [Osoblyvosti obliku na avtotransportnykh pidpryyemstvakh], available at: http://molodyvcheny.in.ua/files/journal/2019/1/58.pdf. (last accessed 10.09.2021).

10. Accountancy: Monograph in 3 parts. Part II. Charts of accounts of accounting / N.M. Malyuga, M. Ya. Steinman, E.P. Borimskaya [Preface. F.F. Butyntsa]. [Schetovedeniye: Monografiya v 3-kh chastyakh. CH. ÍI. Plany schetov bukhgalterskogo uchetatyntsa]. Zhitomir: ZhGTU, 2009. 396 p. 


\section{РЕФЕРАТИ РЕФЕРАТЫ ABSTRACTS}

\section{УДК 657.4.012.2; JEL Classification: M40}

КоваЛЬова Т.В. МЕТОДИЧНІ АСПЕКТИ СКЛАДАННЯ РОБОЧОГО ПЛАНУ РАХУНКІВ ЗА МСФЗ ДЛЯ КОМПАНІЙ АВТОМОБІЛЬНОДОРОЖНЬОГО КОМПЛЕКСУ.

Метою дослідження є висвітлення методики створення робочого плану рахунків за МСФЗ для компаній автомобільно-дорожнього комплексу. Методика дослідження: для досягнення поставленої мети у роботі були використані загальнонаукові і спеціальні методи і прийоми дослідження: теоретичного узагальнення, аналізу і синтезу; системного і комплексного підходу; абстрактно-логічний. Через відсутність регламентації цього питання 3 боку як держави, так і МСФЗ, на практиці можливі труднощі з розробкою робочого плану рахунків у працівників бухгалтерської служби. Результати дослідження: результатом наукової роботи $\epsilon$ теоретичне узагальнення i практичні рекомендації щодо методики складання робочого плану рахунків для компаній автомобільно-дорожнього комплексу, які використовують МСФЗ. Глобалізаційні процеси і політика держави сприяють появі нових компаній, в тому числі і в автомобільно-дорожньому комплексі, які повинні складати фінансову звітність за МСФЗ. Робочий план рахунків повинен забезпечити суцільне охоплення операцій фінансово-господарської діяльності, 3 урахуванням особливостей діяльності автомобільно-дорожнього комплексу, задовольнити потреби управлінського персоналу в аналітичній інформації та бути зручним для використання для фахівців бухгалтерської служби. Наукова новизна: полягає в комплексному дослідженні проблем, пов'язаних 3 розробкою робочого плану рахунків для компаній автомобільно-дорожнього комплексу. Запропоновано використовувати англосаксонський варіант побудови плану рахунків. Практична значущість полягає в тому, що, за відсутності нормативного врегулювання з питань створення робочого плану для компаній автомобільно-дорожнього комплексу, що використовують МСФЗ, вказані у роботі пропозиції дадуть змогу працівникам бухгалтерської служби покращити стан обліку та допомогти складати фінансову звітність.

Ключові слова: робочий план рахунків; автомобільно-дорожній комплекс; міжнародні стандарти; облік; рахунок.

УДК 657.4.012.2; JEL Classification: M40

Ковалева Т.В. МЕТОДИЧЕСКИЕ АСПЕКТЫ СОСТАВЛЕНИЯ РАБОЧЕГО ПЛАНА СЧЕТОВ С УЧЕТОМ МСФО ДЛЯ КОМПАНИЙ АВТОМОБИЛЬНО-ДОРОЖНОГО КОМПЛЕКСА.

Целью исследования является освещение методики создания рабочего плана счетов по МСФО для компаний автомобильно-дорожного комплекса. Методика исследования: для достижения поставленной цели в работе были использованы общенаучные и специальные методы и приемы исследования: теоретического обобщения, анализа и синтеза; системного и комплексного подхода; абстрактно-логический. Из-за отсутствия регламентации этого 
вопроса со стороны как государства, так и МСФО, на практике возможны трудности с разработкой рабочего плана счетов у работников бухгалтерской службы. Результаты исследования: результатом научной работы является теоретическое обобщение и практические рекомендации по методике составления рабочего плана счетов для компаний автомобильно-дорожного комплекса, использующих МСФО. Глобализационные процессы и политика государства способствуют появлению новых компаний, в том числе и в автомобильно-дорожном комплексе, которые должны составлять финансовую отчетность по МСФО. Рабочий план счетов должен обеспечить сплошной охват операций финансово-хозяйственной деятельности, с учетом особенностей деятельности автомобильно-дорожного комплекса, удовлетворить потребности управленческого персонала в аналитической информации и быть удобным в использовании для специалистов бухгалтерской службы. Научная новизна: заключается в комплексном исследовании проблем, связанных с разработкой рабочего плана счетов для компаний автомобильно-дорожного комплекса. Предложено использовать англосаксонский вариант построения плана счетов. Практическая значимость заключается в том, что, при отсутствии нормативного урегулирования по вопросам создания рабочего плана для компаний автомобильно-дорожного комплекса, использующих МСФО, указанные в работе предложения позволят работникам бухгалтерской службы улучшить состояние учета и помочь составлять финансовую отчетность.

Ключевые слова: рабочий план счетов; автомобильно-дорожный комплекс; международные стандарты; учет; счет.

\section{UDK 657.4.012.2; JEL Classification: M40}

Kovalova T.V. METHODOLOGICAL ASPECTS OF DRAWING UP A WORKING PLAN OF ACCOUNTS ACCORDING TO IFRS FOR COMPANIES OF THE AUTOMOBILE AND ROAD COMPLEX.

The purpose of the study is to highlight the methodology of creating a working plan of accounts according to IFRS for companies of the automobile and road complex. Methodology of research: to achieve the purpose in the work were used general scientific and special methods and techniques of research: theoretical generalization, analysis and synthesis; system and complex approach; abstract logical. Due to the lack of regulation of this issue on the part of both the state and the IFRS, in practice there may be difficulties with the development of a working plan of accounts by employees of the accounting service. Results of the research: the result of the scientific work is a theoretical summary and practical recommendations for the methodology of the working plan of accounts for the companies of the automobile and road complex, which use the IFRS. Globalization processes and the policy of our state contribute to the emergence of new companies, including in the automobile and road complex, which must prepare financial statements according to IFRS. The working plan of accounts should provide a comprehensive coverage of operations of financial and economic activities, taking into account the specifics of the automobile and road complex, meet the needs of management personnel in analytical information and be easy to use for specialists of the accounting service. Scientific novelty: 
consists in a comprehensive study of the problems associated with the development of a working plan of accounts for the companies of the automobile and road complex. It is proposed to use the Anglo-Saxon version of the construction of the plan of accounts. The practical significance lies in the fact that, in the absence of regulation on the creation of a work plan for companies of the automobile and road complex, which use the IFRS, the proposals indicated in the work will enable employees of the accounting service to improve accounting and help fold the financial statements.

Keywords: working plan of accounts; automobile and road complex; international standards; accounting; account.

\section{Відомості про авторів /Сведения об авторах / About the Authors}

Ковальова Тетяна Володимирівна - кандидат економічних наук, доцент, Харківський національний автомобільно-дорожній університет, доцент кафедри обліку і оподаткування; м. Харків,Україна; ORCID: https://orcid.org/0000-00031250-2019; e-mail: kovaleva64@ukr.net. Моб. 063-262-36-36.

Ковалева Татьяна Владимировна - кандидат экономических наук, доцент, Харьковский национальный автомобильно-дорожный университет, доцент кафедры учета и налогообложения.

Kovalova Tetiana Volodimipovna - Candidate of Sciences (Economics), Kharkov National Automobile and Highway University, Associate Professor at the Department of account, taxation; Kharkiv, Ukraine. 